\title{
Poly[(R)-3-hydroxybutyrate]: the Green Biodegradable Bioplastics of the Future!
}

\section{Yaser Dhaman* and Charles U Ugwu}

Department of Chemical Engineering, Ryerson University, Toronto, Ontario, Canada

At present, most plastic materials that are widely used on daily basis are non-biodegradable products derived from fossil fuels. Due to the increase in population and industrialization, there is now increased awareness of the impact of these non-biodegradable plastics on the environment. A lot of efforts are now geared towards developing various biodegradable plastics. Biodegradable polymers can be broadly classified under polynucleotides, polyamides, polysaccharides, polyoxoesters, polythioesters, polyphosphates, polyisoprenoides and polyphenols [1]. Poly[(R)-3-hydroxybutyrate] (PHB), the most widely studied member of PHA (polyoxoesters) is very promising as a biodegradable plastic because of its material properties which are comparable to those of the polypropylene [2]. PHB is a natural polymer produced by many bacteria as carbon and energy storage materials. PHB can be synthesized from renewable low-cost feedstocks and its polymerizations are operated under mild process conditions with minimal environmental impact [3]. A good number of microbial strains are known to produce PHB under certain growth conditions. Among these groups of bacteria, R. eutropha and A. latus are the most widely studied [4,5], and very high PHB contents up to $76 \%(\mathrm{w} / \mathrm{w})$ have been reported [6]. Furthermore, PHB can be degraded in both aerobic and anaerobic environments, without forming any toxic products [7]. PHB can be used as biomaterials (e.g., bone regeneration, dressing of wounds, sutures, etc.) [8]. In addition, it can be used as packaging materials [9]. Some studies have also shown that PHB can serve as micro-particulate carrier of drugs [10].

In the past few years, a few companies have tried to commercialize PHB. In 1980s, Imperial Chemical Industries initiated pilot scale production of PHB. Following this development, Monsanto bought all the patents for making PHB from ICI/Zeneca and started it under the trade name, "Biopol". More recently, a company called Metabolix, took over from Monsato and formed an alliance with Archer Daniels Midland Company, in 2004, to produce PHB commercially, starting with a 100-million-pound-per-year plant to be established in the US. It has been predicted that production of 50 billion pounds of PHB would account for about half of the petrochemical plastics currently used in the United States, and this would invariably reduce oil imports by over 200-230 million barrels per year, improving the U.S. trade balance by $\$ 6-9$ billion per year, based on the estimated oil price at $\$ 30-40$ per barrel.

It is envisaged that replacement of petroleum-based plastics with PHB would have several economic advantages. However, to make

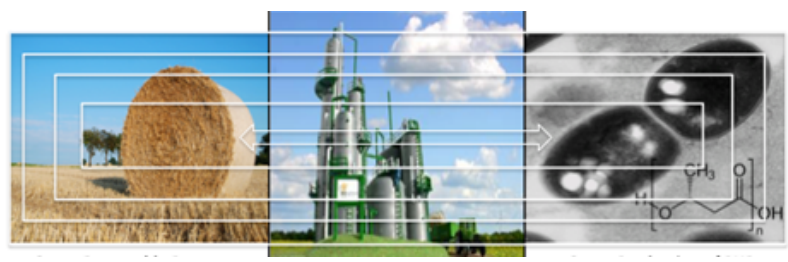

Figure 1: Fermentative Production of PHB. fermentative production of PHB (Figure 1) economically competitive with those of the petroleum-based plastics, cheap renewable materials (e.g. agro industrial residues) are under research [11]. Although most fermentative production of PHB (Figure 1) have been examined using starchy and soluble sugars, no information is available regarding the use of cellulose materials as carbon substrates. The big question remains if it is feasible to design and pilot a continuous biorefinery system to utilize crop residues for green production of the future biodegradable bioplastics.

\section{References}

1. Steinbuchel A, Lke-Eversloh T (2003) Metabolic engineering and pathway construction for biotechnological production of relevant polyhydoxyalkanoates in microorganisms. Biochem Eng 16: 81-96.

2. Doi $Y(1990)$ Microbial Polyesters. VCH publishers, New York, USA.

3. Braunegg G, Sonnleitner B, Lafferty RM (1978) A rapid gas chromatographic method for the determination of poly-hydroxybutyric acid in microbial biomass. Eur J Appl Microbiol 6: 29-37.

4. Hahn SK, Chang YK, Lee SY (1995) Recovery and characterization of poly(3hydroxybutyric acid) synthesized in Alcaligeneseutrophusand recombinant Escherichia coli Appl. Environ Microbiol 61: 34-39.

5. Palleroni NI, Palleroni AV (1978) Alcaligeneslatus a new species of hydrogen utilizing bacteria. Int J Syst Bacteriol 28: 416-428.

6. Tokiwa Y, Ugwu CU (2007) Biotechnological production of (R)-3-hydroxybutyric acid monomer. J Biotechnol 132: 264-272.

7. Nishida H, Tokiwa Y (1993)Effects of higher-order structure of poly (3-hydroxybutyrate) on its biodegradation II Effects of crystal structure on microbial degradation II Effects of crystal structure on microbial degradation. J Polym Degrad 1: 65-80.

8. Bernd HE, Kunze C, Freier T, Sternberg K, Kramer S, et al. (2009) Poly(3hydroxybutyrate) (PHB) patches for covering anterior skull base defects - an animal study with minipigs. Acta Otolaryngol 129:1010-1017.

9. Bucci DZ, Tavares LBB, Sell I (2007) Biodegradation and physical evaluation of PHB packaging. Polymer Testing 26: 908-915.

10. Cheng C, Chung Him Y, Yin Chung C, Peter HFY, Man Ken C (2006) Biodegradable nanoparticles of amphiphilictriblock copolymers based on poly(3-hydroxybutyrate) and poly(ethylene glycol) as drug carriers. Biomaterials 27: 4804-4814

11. Haas R, Jin B, Zepf FT (2008) Production of polyhydroxybutyrate from waste Potato Starch. Biosc Biotechnol Biochem 72: 253-256.

*Corresponding author: Yaser Dahman, Department of Chemical Engineering Ryerson University, Toronto, Ontario, Canada, Tel: 1-416-979-5000, ext.4080; Fax: 1-416-979-5083; E-mail: ydahman@ryerson.ca

Received January 01, 2014; Accepted January 04, 2014; Published Februay 04, 2014

Citation: Dhaman Y, Ugwu CU (2013) Poly[(R)-3-hydroxybutyrate]: the Green Biodegradable Bioplastics of the Future! Ferment Technol 3: e120. doi:10.4172/2167-7972.1000e120

Copyright: (c) 2013 Dhaman $\mathrm{Y}$, et al. This is an open-access article distributed under the terms of the Creative Commons Attribution License, which permits unrestricted use, distribution, and reproduction in any medium, provided the original author and source are credited. 